Siti Hajar ${ }^{1}$

Yenni Fitra Surya ${ }^{2}$

\section{PENERAPAN MODEL PEMBELAJARAN KOOPERATIF TWO STAY TWO STRAY UNTUK MENINGKATKAN AKTIVITAS DAN HASIL BELAJAR IPA SISWA SEKOLAH DASAR}

\begin{abstract}
Abstrak
Masalah dalam penelitian ini adalah rendahnya aktivitas dan hasil belajar IPA sebesar 58,3\% atau 14 siswa dari 24 siswa yang mencapai tingkat ketuntasan. Tujuan penelitian adalah untuk meningkatkan aktivitas dan hasil belajar IPA dengan menerapkan model Kooperatif Two Stay Two Stray. Jenis penelitian yang digunakan adalah Penelitian Tindakan Kelas (PTK) yang terdiri dari empat tahapan dalam setiap siklusnya yaitu perencanaan, pelaksanaan, pengamatan, dan refleksi. Penelitian dilaksanakan sebanyak dua siklus yang setiap siklusnya terdiri dari dua pertemuan. Alat pengumpul data penelitian adalah lembar observasi dan soal tes. Teknik analisis data menggunakan teknik analisis kualitatif dan kuantitatif. Hasil penelitian pada siklus I rata-rata komponen aktivitas siswa secara klasikal sebesar 8,8 dengan persentase siswa aktif 73\% (kategori cukup), siklus II komponen aktivitas klasikal meningkat sebesar 1,7 sehingga menjadi 10,5 dengan persentase siswa aktif meningkat sebesar 14,5\% sehingga menjadi 87,5\% (kategori aktif). Adapun rata-rata hasil belajar kognitif siswa pada siklus I sebesar 75,3 (kriteria baik) dan meningkat sebesar 10,5 sehingga siklus II menjadi 85,8 (kriteria baik). Dengan demikian, pembelajaran IPA dengan menerapkan model Kooperatif Two Stay Two Stray dapat meningkatkan aktivitas dan hasil belajar IPA siswa.
\end{abstract}

Kata kunci: Aktivitas, Kooperatif Two Stay Two Stray, Hasil belajar.

\begin{abstract}
The problem in this research is the low of activity and result of study of science equal to $58,3 \%$ or 14 student reaching level of mastery. The purpose of this research is to increase the activity and result of science learning by applying cooperative model two stay two stray. The type of research (PTK) consisting of four stages in each cycle that is planning, implementation, observation, and reflection. The study was conducted in two cycles which each cycle consisted of two meetings. Research collection is an observation sheet and tets question. Data analysis techniques using qualitative and quantitative analysis techniques. The results of research on the cycle I average component of student activity in the classical 8,8 with the persentase of active students $73 \%$ (enough category), cycle II component of classical activity increased 1,7 so that become 10,5 with active student persentage increased by $14,5 \%$ so become $87,5 \%$ (active category). While the average cognitive learning out comes of students in cycle I of 75,3 (good criteria) and increased by 10,5 so that the cycle II to 85,8 (good criteria).Thus, IPA learning by applying cooperative model of two stay two stray can increase student learning activityand outcomes.
\end{abstract}

Keywords: Activity, Cooperative Two Stay Two Stray, Learning result

\footnotetext{
${ }^{1}$ Pendidikan Guru Sekolah Dasar Universitas Pahlawan Tuanku Tambusai

Email: sitihajar.ys@gmail.com

${ }^{2}$ Pendidikan Guru Sekolah Dasar Universitas Pahlawan Tuanku Tambusai
} 


\section{PENDAHULUAN}

Pendidikan IPA merupakan salah satu mata pelajaran yang mengembangkan pemahaman tentang berbagai macam gejala alam, konsep, dan prinsip IPA yang bermanfaat dan dapat diterapkan dalam kehidupan sehari-hari. Hal ini sejalan dengan pendapat Saudana, dkk (2010: 5) dalam (Dewi, Rati, \& Dibia, 2016) menyatakan "pendidikan IPA di sekolah dasar diselenggarakan dengan tujuan untuk mengembangkan sikap dan kemampuan serta memberikan pengetahuan dan keterampilan dasar yang diperlukan untuk hidup dalam masyarakat". Dengan pendapat tersebut pembelajaran IPA sangat penting untuk dipelajari oleh siswa Sekolah Dasar. Karena dapat memupuk rasa ingin tahu peserta didik tentang peristiwa-peristiwa yang terjadi di alam secara alami serta dapat membuat keberhasilan di dalam proses belajar mengajar.

Depdikbud (dalam Trianto, 2009) menyatakan bahwa pembelajaran IPA memiliki fungsi yang fundamental dalam mengembangkan kemampuan berpikir kritis, kreatif, dan inovatif. Agar tujuan tersebut dapat tercapai, maka pembelajaran IPA perlu dilaksanakan dengan cara/ strategi yang tepat agar dapat melibatkan peserta didik secara aktif dalam proses pembelajaran dan pengembangan sikap ilmiah. (Sukarsa, Dantes, \& Arini, 2014)

Selanjutnya pembelajaran IPA dilakukan strategi sedemikian rupa dengan mempertimbangkan mutu pembelajaran yang berkelanjutan serta kemajuan IPTEK. Pada pembelajaran IPA lebih menuntut peserta didik untuk membangun sendiri pengetahuannya melalui penerapan keterampilan proses. Untuk meningkatkan mutu pembelajaran khususnya pembelajaran IPA, tentu banyak tantangan yang harus dihadapi.

Nur dan Wikandari (dalam Trianto: 2017) bahwa proses belajar mengajar IPA lebih ditekankan pada pendekatan keterampilan proses, hingga peserta didik dapat menemukan fakta-fakta, membangun konsep-konsep, teori-teori dan sikap ilmiah peserta didik itu sendiri yang akhirnya dapat berpengaruh positif terhadap kualitas proses pendidikan maupun produk pendidikan. Selama ini proses pembelajaran hanya menghafalkan fakta, prinsip atau teori saja. Untuk itu perlu dikembangkan suatu model pembelajaran IPA yang melibatkan peserta didik secara aktif dalam kegiatan pembelajaran untuk menemukan atau menerapkan sendiri ide-idenya. Guru hanya memberi tangga yang membantu peserta didik untuk mencapai tingkat pemahaman yang lebih tinggi, namun harus diupayakan agar peserta didik dapat menaiki tangga tersebut.

Kenyataanya dalam proses pembelajaran IPA di Sekolah Dasar, dijumpai kegiatan pembelajaran hanya berupa penyampaian konsep kepada peserta didik melalui transfer pengetahuan dari guru kepada peserta didik, membaca buku, tanpa memberikan pengalaman langsung kepada peserta didik untuk mengkontruksi sendiri pengetahuannya. Hal ini diperkuat dari hasil observasi pembelajaran IPA di kelas IV di SDN 007 Sungai Agung. Berdasarkan pengamatan terlihat aktivitas belajar peserta didik masih kurang. Proses pembelajaran yang dilaksanakan masih terpusat pada guru, guru kurang melibatkan peserta didik dalam proses belajar, umumnya guru menggunakan metode ceramah yang mengakibatkan peserta didik merasa bosan dalam proses pembelajaran, kurangnya mendengarkan penjelasan guru dalam menjelaskan pelajaran mengakibatkan minimnya aktivitas peserta didik selama proses pembelajaran. Peserta didik sibuk dengan diri nya sendiri dan seringnya peserta didik meminta izin untuk keluar kelas selama proses belajar mengajar berlangsung. Peserta didik enggan bertanya kepada teman atau guru saat mereka mengalami kesulitan dalam belajar, sehingga situasi pembelajaran menjadi kurang kondusif dan peserta didik kurang 
memahami materi dan informasi yang disampaikan oleh guru, yang mengakibatkan rendahnya hasil belajar siswa.

Berdasarkan hasil wawancara penulis dengan guru kelas IV SDN 007 Sungai Agung pada bulan Februari 2018, terungkap bahwa nilai rata-rata hasil belajar siswa kelas IV secara klasikal pada mata pelajaran IPA masih di bawah Kriteria Ketuntasan Minimal (KKM) yang ditentukan oleh sekolah yaitu $\geq 70$. Dapat dilihat pada tabel 1.1.

Tabel 1.1 Nilai Rata-rata Ulangan Harian Kelas IV SDN 007 Sungai Agung Semester Genap Tahun Pelajaran 2017/2018 pada Mata Pelajaran IPA

\begin{tabular}{|l|c|c|c|c|c|c|}
\hline $\begin{array}{c}\text { Tahun } \\
\text { pelajaran }\end{array}$ & $\begin{array}{c}\text { Jumlah } \\
\text { siswa }\end{array}$ & $\begin{array}{c}\text { Jumlah } \\
\text { siswa } \\
\text { yang } \\
\text { tuntas }\end{array}$ & $\begin{array}{c}\text { Jumlah } \\
\text { siswa } \\
\text { yang } \\
\text { belum } \\
\text { tuntas }\end{array}$ & KKM & $\begin{array}{c}\text { Persentas } \\
\text { e } \\
\text { ketuntasa } \\
\text { n }\end{array}$ & $\begin{array}{c}\text { Persentase } \\
\text { belum } \\
\text { tuntas }\end{array}$ \\
\hline $\begin{array}{l}2017 / 201 \\
8\end{array}$ & 24 & 14 & 10 & 70 & $58,3 \%$ & $41,7 \%$ \\
\hline
\end{tabular}

Sumber: Buku Nilai Guru

Adanya permasalahan tersebut, guru dituntut kreatif untuk menciptakan suasana belajar yang baik dan tujuan dari proses tersebut bisa tercapai sesuai dengan yang diinginkan. Diantaranya guru menyesuaikan, memilih dan menerapkan model pembelajaran yang sesuai dengan materi yang akan diajarkan, agar menarik minat dan peran aktif peserta didik dalam pembelajaran. Sebab, prestasi peserta didik salah satunya ditunjang dengan model pembelajaran yang tepat. Salah satu model pembelajaran yang sesuai dengan permasalahan di atas adalah model pembelajaran kooperatif. Model pembelajaran kooperatif adalah salah satu model pembelajaran yang dapat meningkatkan aktivitas peserta didik, interaksi antara peserta didik, kerja sama antar peserta didik untuk penguasaan materi pembelajaran dan meningkatkan motivasi peserta didik untuk aktif dalam proses pembelajaran, sehingga setiap peserta didik akan bertanggung jawab untuk melakukan yang terbaik. Pengelompokan heterogenitas merupakan ciri yang menonjol dalam pembelajaran kooperatif. (Trianto 2011: 56) Di dalam kelas kooperatif siswa belajar bersama dalam kelompok-kelompok kecil yang terdiri dari 4-6 orang siswa yang sederajat tetapi heterogen, kemampuan, jenis kelamin, suku/ras, dan satu sama lain saling membantu.

Selanjutnya Trianto (2011: 57) mengemukakan bahwa dalam menerapkan model pembelajaran kooperatif setidaknya mempunyai tiga tujuan pembelajaran. Tujuan yang pertama yaitu peserta didik bekerja sama untuk belajar dan bertanggung jawab pada kemajuan belajar. Tujuan kedua yaitu memaksimalkan belajar peserta didik untuk peningkatan prestasi akademik dan pemahaman baik secara individu maupun secara kelompok. Tujuan ketiga dapat mengurangi kesenjangan pendidikan khususnya dalam wujud input pada level individual.

Salah satu model pembelajaran kooperatif adalah model Two Stay Two Stray (TSTS) atau dua tinggal dua tamu. Dalam model pembelajaran Two Stay Two Stray peserta didik bekerjasama dalam kelompok berempat seperti biasa. Setelah selesai, dua orang dari masing-masing bertamu kedua kelompok yang lain. Dua orang yang tinggal dalam kelompok bertugas membagikan hasil kerja dan informasi mereka ke tamu. Tamu mohon diri dan kembali ke kelompok mereka sendiri lalu melaporkan temuan mereka dari kelompok lain, kelompok mencocokkan dan membahas hasil kerja mereka. Dengan permainan yang dilakukan dapat merangsang minat peserta didik, sehingga dengan 
proses pembelajaran yang demikian akan lebih menarik minat peserta didik untuk terlibat dalam proses pembelajaran dan beraktivitas. Model pembelajaran Two Stay Two Stray terdiri dari empat langkah yakni: tahap penyajian kelas, belajar dengan kelompok, membagikan informasi dan membahas hasil kerja kelompok.

Semakin aktif peserta didik selama proses pembelajaran, semakin banyak pula pengalaman belajar yang akan tercapai. Adapun kelebihan dari model pembelajaran kooperatif Two Stay Two Stray diantaranya: memberikan kesempatan kepada suatu kelompok untuk dapat berbagi informasi dengan kelompok lain mengenai tugas atau permasalahan yang mereka diskusikan, meningkatkan hasil belajar peserta didik, menghindari rasa bosan yang disebabkan pembentukan kelompok secara permanen, dan melatih kemampuan peserta didik dalam memberikan informasi kepada temannya yang di dalam kelompok maupun diluar kelompok.

Berdasarkan uraian di atas maka peneliti ingin melakukan perbaikan dalam proses belajar mengajar dengan menerapkan dan memperkenalkan suatu model pembelajaran yang belum diterapkan di SDN 007 Sungai Agung khususnya pada pelajaran IPA yakni dengan "Penerapan Model Pembelajaran Kooperatif Two Stay Two Stray untuk Meningkatkan Aktivitas dan Hasil Belajar IPA Siswa Sekolah Dasar', yang nantinya diharapkan dapat memperbaiki aktivitas dan hasil belajar IPA.

\section{METODE PENELITIAN}

Penelitian ini merupakan Penelitian Tindakan Kelas, yaitu penelitian reflektif oleh pelaku tindakan yang dilakukan oleh sendiri untuk memperbaiki proses pembelajaran yang menjadi tanggung jawabnya, penelitian ini diharapkan dapat memberikan cara atau prosedur baru untuk memperbaiki dan meningkatkan profesionalisme guru/pendidik dalam proses pembelajaran di kelas.

Menurut Surya, Y (2017: 14) Penelitian tindakan kelas merupakan penelitian yang dilakukan oleh guru di dalam kelasnya sendiri melalui refleksi diri dengan tujuan utama memperbaiki kinerjanya sebagai guru.

Penelitian PTK yang dilakukan bertujuan untuk mengetahui penerapan model pembelajaran berdasarkan masalah terhadap rendahnya aktivitas dan hasil belajar siswa pada matapelajaran IPA SDN 007 Sunai Agung.

Penelitian tindakan kelas telah dilaksanakan di SDN 007 Sungai Agung. Pemilihan tempat ini sebagai lokasi penelitian dikarenakan disanalah permasalahannya terjadi dan peneliti temukan khususnya pada kelas IV dan di kelas ini belum pernah menerapkan model pembelajaran kooperatif Two Stay Two Stray pada pembelajaran IPAPenelitian ini dilaksankan di kelas IV SDN 007 Sungai Agung Tahun Akademis 2017/2018, dengan subjek penelitian yang berjumlah 24 orang peserta didik, yang terdiri dari 10 siswa Laki-laki dan 14 siswa perempuan.

Penelitian ini telah dilaksanakan pada semester genap bulan April sampai dengan Mei 2018 prosedur penelitian mengikuti langkah-langkah (siklus). Siklus penelitian ini diawali dengan perencanaan tindakan (planning), penerapan tindakan (observation), dan melakukan refleksi (reflection).

Penelitian tindakan kelas di laksanakan dalam bentuk siklus yang menyeluruh dan bertujuan untuk memperbaiki praktik pembelajaran. Sisklus dimulai dengan pengamatan tindakan (planning), pelaksanaan tindakan (action), penobservasian hasil tindakan dan pelaksanaan refleksi (reflection). 
Teknik pengumpulan data merupakan alat yang digunakan pada waktu me-laksanakan penelitian dalam upaya mencari dan mengumpulkan data penelitian.

Instrumen yang digunakan untuk pengumpulan data adalah lembar tes dan lembar observasi kegiatan siswa dan lembar kegiatan guru.

\section{HASIL DAN PEMBAHASAN}

\section{Siklus I}

\section{Hasil Belajar Siswa pada Siklus I}

Hasil rekapitulasi pada siklus I dapat dilihat pada tabel 4.3.

Tabel 4.3 Rekapitulasi Hasil Belajar IPA Siklus I Materi Sumber Daya Alam SDN 007 Sungai Agung

\begin{tabular}{|c|c|c|c|}
\hline \multirow[t]{2}{*}{ No. } & \multirow[t]{2}{*}{ Interval } & \multicolumn{2}{|c|}{ Tindakan Siklus I } \\
\hline & & Jumlah & Persentase \\
\hline 1. & $\begin{array}{l}\text { 86-100 (Baik } \\
\text { Sekali) }\end{array}$ & 3 Siswa & $13 \%$ \\
\hline 2. & 71-85 (Baik) & $\begin{array}{c}13 \\
\text { Siswa }\end{array}$ & $54 \%$ \\
\hline 3.. & 56-70 (Cukup) & $\begin{array}{c}18 \\
\text { Siswa }\end{array}$ & $33 \%$ \\
\hline 4. & 41-55 (Kurang) & 0 & 0 \\
\hline 5. & $\begin{array}{c}<40 \text { (Kurang } \\
\text { Sekali) }\end{array}$ & 0 & 0 \\
\hline & Jumlah siswa & 24 & $100 \%$ \\
\hline & Rata-rata & 75,31 & \\
\hline & Kategori & Baik & \\
\hline & mlah yang tuntas & $\begin{array}{c}16 \\
\text { Siswa }\end{array}$ & $67 \%$ \\
\hline & $\begin{array}{l}\text { mlah yang tidak } \\
\text { tuntas }\end{array}$ & 8 Siswa & $33 \%$ \\
\hline
\end{tabular}

Rata-rata hasil belajar siswa pada siklus I meningkat dari pra tindakan yaitu, 70,4 dengan kategori Cukup menjadi 75,31 dengan kategori baik, siswa yang mendapatkan nilai baik sekali (86100) berjumlah 3, siswa dengan persentase 13\%. Siswa yang mendapatkan nilai baik (71-85) berjumlah 13 orang dengan persentase $54 \%$, karena siswa tersebut saat guru memberikan sub pokok pada siswa dalam berdiskusi siswa tersebut saling bekerjasama dalam kelompok dan terlibat aktif dalam kerja kelompok, yang mendapat cukup terdapat 8 siswa dengan persentase 33\%, siswa yang mendapat nilai cukup karena saat guru menjelaskan banyak siswa yang bercerita di dalam kelas sehingga apa yang dijelaskan oleh guru siswa tersebut tidak mengerti karena dia tidak memperhatikan guru di depan kelas dan saat guru menjelaskan langkah kerja dalam berdiskusi siswa kurang menyimak apa yang disampaikan oleh guru tersebut, yang mendapat nilai kurang (41-55) berjumlah 0 , dengan persentase $0 \%$. Dan siswa yang mendapatkan nilai kurang sekali $(<40)$ berjumlah 0,dengan persentase $0 \%$. Ketuntasan hasil belajar IPA dapat dilihat pada tabel 4.4. 
Tabel 4.4 Ketuntasan Hasil Belajar Siswa Kelas IV SDN 007 Sungai Agung pada Siklus I

\begin{tabular}{|c|c|c|c|c|}
\hline \multirow{2}{*}{ Nilai } & \multicolumn{3}{|c|}{ Ketuntasan Belajar } \\
\cline { 2 - 5 } & \multicolumn{2}{|c|}{ Tuntas } & \multicolumn{2}{c|}{ Tidak Tuntas } \\
\cline { 2 - 5 } & Jumlah & Persentase & Jumlah & $\begin{array}{c}\text { Persent } \\
\text { ase }\end{array}$ \\
\hline Siklus I & $\begin{array}{c}16 \\
\text { siswa }\end{array}$ & $67 \%$ & 8 siswa & $33 \%$ \\
\hline
\end{tabular}

\section{Hasil Peningkatan Aktivitas Belajar Siswa pada Siklus I}

Hasil rekapitulasi pada siklus I dapat dilihat pada tabel 4.5

Tabel 4.5 Rekapitulasi Hasil Peningkatan Aktivitas Belajar IPA Siklus I Materi Sumber Daya Alam SDN 007 Sungai Agung

\begin{tabular}{|c|c|c|c|}
\hline \multirow{2}{*}{ No. } & Interval & \multicolumn{2}{|c|}{ Tindakan Siklus I } \\
\cline { 3 - 4 } & & Jumlah & Persentase \\
\hline 1. & $\begin{array}{c}\text { 86-100 (Baik } \\
\text { Sekali) }\end{array}$ & 6 Siswa & $25 \%$ \\
\hline 2. & $71-85$ (Baik) & 9 Siswa & $37,5 \%$ \\
\hline $3 .$. & $56-70$ (Cukup) & 9 Siswa & $37,5 \%$ \\
\hline 4. & $\begin{array}{c}41-55 \\
\text { (Kurang) }\end{array}$ & 0 & 0 \\
\hline 5. & $\begin{array}{c}<40 \text { (Kurang } \\
\text { Sekali) }\end{array}$ & 0 & 0 \\
\hline \multicolumn{2}{|c|}{ Jumlah siswa } & $\mathbf{2 4}$ & $\mathbf{1 0 0 \%}$ \\
\hline \multicolumn{2}{|c|}{ Rata-rata } & $\mathbf{8 , 8}$ & \\
\hline \multicolumn{2}{|c|}{ Persentase Klasikal } & $\mathbf{7 3 \%}$ & \\
\hline \multicolumn{3}{|c|}{ Kategori } & Baik \\
\hline
\end{tabular}

Rata-rata hasil peningkatan aktivitas belajar siswa pada siklus I meningkat dari pra tindakan yaitu, 47\% dengan kategori kurang menjadi 73\% dengan kategori baik, siswa yang mendapatkan nilai baik sekali (86-100) berjumlah 6 , siswa dengan persentase $25 \%$. Siswa yang mendapatkan nilai baik (71-85) berjumlah 9 orang dengan persentase 37,5\%, karena siswa tersebut saat guru memberikan sub pokok pada siswa dalam berdiskusi siswa tersebut saling bekerjasama dalam kelompok dan terlibat aktif dalam kerja kelompok, yang mendapat cukup terdapat 9 siswa dengan persentase $37,5 \%$, siswa yang mendapat nilai cukup karena saat guru menjelaskan banyak siswa yang bercerita di dalam kelas sehingga apa yang dijelaskan oleh guru siswa tersebut tidak mengerti karena dia tidak memperhatikan guru di depan kelas dan saat guru menjelaskan langkah kerja dalam berdiskusi siswa kurang menyimak apa yang disampaikan oleh guru tersebut, yang mendapat nilai kurang (41-55) berjumlah 0, dengan persentase 0\%. Dan siswa yang mendapatkan nilai kurang sekali (<40) berjumlah 0 , dengan persentase $0 \%$.

\section{Silkus II}

\section{Hasil Belajar Siswa pada Siklus II}

Hasil rekapitulasi pada siklus II dapat dilihat pada tabel 4.6.

Tabel 4.6 Rekapitulasi Hasil Belajar IPA Siklus II Materi Sumber Daya Alam SDN 007 Sungai Agung 


\begin{tabular}{|c|c|c|c|}
\hline \multirow[t]{2}{*}{ No } & \multirow[t]{2}{*}{ Interval } & \multicolumn{2}{|c|}{ Tindakan Siklus II } \\
\hline & & Jumlah & Persentase \\
\hline 1. & $\begin{array}{c}\text { 86-100 (Baik } \\
\text { Sekali) }\end{array}$ & $\begin{array}{c}13 \\
\text { Siswa }\end{array}$ & $54 \%$ \\
\hline 2. & 71-85 (Baik) & 8 Siswa & $33 \%$ \\
\hline 3.. & 56-70 (Cukup) & 3 Siswa & $13 \%$ \\
\hline 4. & 41-55 (Kurang) & 0 & 0 \\
\hline 5. & $\begin{array}{c}<40 \text { (Kurang } \\
\text { Sekali) }\end{array}$ & 0 & 0 \\
\hline & umlah siswa & 24 & $100 \%$ \\
\hline & Rata-rata & 85,8 & \\
\hline & Kategori & Baik & \\
\hline & lah yang tuntas & $\begin{array}{c}22 \\
\text { Siswa }\end{array}$ & $92 \%$ \\
\hline & $\begin{array}{l}\text { lah yang tidak } \\
\text { tuntas }\end{array}$ & 2 Siswa & $8 \%$ \\
\hline
\end{tabular}

Rata-rata hasil belajar siswa pada siklus II meningkat dari siklus I yaitu, 75,31 dengan kategori baik menjadi 85,8 dengan kategori baik, siswa yang mendapatkan nilai baik sekali (86-100) berjumlah 3siswa dengan persentase $13 \%$ siswa. Meningkat pada siklus II yaitu 13 orang dibanding siklus I yaitu 54\%. Karna pada siklus II siswa telah memahami langkah-langkah model pembelajaran dengan baik dan guru telah memberikan penguatan kepada siswa dengan baik, Siswa yang mendapatkan nilai baik (71-85) berjumlah 13 orang dengan persentase 54\%, dan pada siklus II berjumlah 8 orang karena siswa tersebut saat guru memberikan sub pokok pada siswa dalam berdiskusi siswa tersebut saling bekerjasama dalam kelompok dan terlibat aktif dalam kerja kelompok, siswa yang mendapat cukup pada siklus II berjumlah 3 siswa dengan persentase 13\% dibanding siklus I berjumlah 8 siswa, karena siswa pada siklus II siswa telah memahami langkah langkah Two Stay Two Stray, dan juga guru telah membentuk kelompok dengan baik berdasarkan kemampuan siswa dan siswa juga telah memperhatikan guru di depan kelas, yang mendapat nilai kurang (41-55) berjumlah 0, siswa dengan persentase 0\%. Dan siswa yang mendapatkan nilai kurang sekali $(<40)$ berjumlah 0, siswa dengan persentase $0 \%$. Ketuntasan hasil belajar IPA dapat dilihat pada tabel 4.7 .

Tabel 4.7 Ketuntasan Hasil Belajar Siswa Kelas IV SDN 007 Sungai Agung pada Siklus II

\begin{tabular}{|c|c|c|c|c|}
\hline \multirow{2}{*}{ Nilai } & \multicolumn{3}{|c|}{ Ketuntasan Belajar } \\
\cline { 2 - 5 } & \multicolumn{2}{|c|}{ Tuntas } & \multicolumn{2}{c|}{ Tidak Tuntas } \\
\cline { 2 - 5 } & Jumlah & Persentase & Jumlah & Persentase \\
\hline $\begin{array}{c}\text { Siklus } \\
\text { II }\end{array}$ & $\begin{array}{c}22 \\
\text { siswa }\end{array}$ & $92 \%$ & $\begin{array}{c}2 \\
\text { siswa }\end{array}$ & $8 \%$ \\
\hline
\end{tabular}

\section{Hasil Peningkatan Aktivitas Belajar Siswa pada Siklus II}

Hasil rekapitulasi pada siklus II dapat dilihat pada tabel 4.8 
Tabel 4.8 Rekapitulasi Hasil Peningkatan Aktivitas Belajar IPA Siklus II Materi Sumber Daya Alam SDN 007 Sungai Agung

\begin{tabular}{|c|c|c|c|}
\hline \multirow{2}{*}{ No. } & Interval & \multicolumn{2}{|c|}{ Tindakan Siklus II } \\
\cline { 3 - 4 } & & Jumlah & Persentase \\
\hline 1. & $\begin{array}{c}86-100 \text { (Baik } \\
\text { Sekali) }\end{array}$ & $\begin{array}{c}17 \\
\text { Siswa }\end{array}$ & $71 \%$ \\
\hline 2. & $71-85$ (Baik) & 5 Siswa & $21 \%$ \\
\hline $3 .$. & $56-70$ (Cukup) & 2 Siswa & $8 \%$ \\
\hline 4. & $41-55$ (Kurang) & 0 & 0 \\
\hline 5. & $\begin{array}{c}<40 \text { (Kurang } \\
\text { Sekali) }\end{array}$ & 0 & 0 \\
\hline \multicolumn{2}{|c|}{ Jumlah siswa } & $\mathbf{2 4}$ & $\mathbf{1 0 0 \%}$ \\
\hline Rata-rata & $\mathbf{1 0 , 5}$ & \\
\hline Persentase Klasikal & $\mathbf{8 7 , 5 \%}$ & \\
\hline \multicolumn{3}{|c|}{ Kategori } & $\begin{array}{c}\text { Baik } \\
\text { Sekali }\end{array}$ \\
\hline
\end{tabular}

Rata-rata hasil peningkatan aktivitas belajar siswa pada siklus II meningkat dari pra tindakan yaitu, 43\% dengan kategori kurang menjadi 73\% dengan kategori baik, siswa yang mendapatkan nilai baik sekali (86-100) berjumlah 17, siswa dengan persentase $71 \%$. Siswa yang mendapatkan nilai baik (71-85) berjumlah 5 orang dengan persentase $21 \%$, karena siswa tersebut saat guru memberikan sub pokok pada siswa dalam berdiskusi siswa tersebut saling bekerjasama dalam kelompok dan terlibat aktif dalam kerja kelompok, yang mendapat cukup terdapat 2 siswa dengan persentase $8 \%$, siswa yang mendapat nilai cukup karena saat guru menjelaskan siswa bercerita sehingga apa yang dijelaskan oleh guru siswa tersebut tidak mengerti karena dia tidak memperhatikan guru di depan kelas dan saat guru menjelaskan langkah kerja dalam berdiskusi siswa kurang menyimak apa yang disampaikan oleh guru tersebut, yang mendapat nilai kurang (41-55) berjumlah 0 , dengan persentase $0 \%$. Dan siswa yang mendapatkan nilai kurang sekali $(<40)$ berjumlah 0 , dengan persentase $0 \%$.

\section{Perbandingan Hasil Tindakan Tiap Siklus}

\section{1).Perbandingan Hasil Belajar Siswa}

Perbandingan hasil belajar siswa dari pratindakan, siklus I, dan siklus II pada materi sumber daya alam pada model Two Stay Two Stray pada tabel 4.9.

Tabel 4.9 Perbandingan Peningkatan Hasil Belajar Siswa

\begin{tabular}{|l|l|l|l|c|}
\hline No. & Keterangan & $\begin{array}{l}\text { Pra } \\
\text { tindakan }\end{array}$ & $\begin{array}{l}\text { Siklus } \\
\text { I }\end{array}$ & $\begin{array}{l}\text { Siklus } \\
\text { II }\end{array}$ \\
\hline 1. & Nilai rata-rata & 70,4 & 75,31 & 85,8 \\
\hline 2. & $\begin{array}{l}\text { Presentase } \\
\text { Ketuntasan } \\
\text { Hasil Belajar }\end{array}$ & $58 \%$ & $67 \%$ & $92 \%$ \\
\hline
\end{tabular}

Berdasarkan tabel 4.9, diketahui bahwa nilai rata-rata siswa pada pra tindakan adalah 70,4 pada siklus I meningkat menjadi 75,31 kemudian pada siklus II mengalami peningkatan menjadi 85,8 sedangkan persentase ketuntasan hasil belajar pada pratindakan adalah 58\%, pada siklus I meningkat menjadi 67\%, kemudian pada siklus II meningkat menjadi 92\%. Hal ini menunjukkan bahwa adanya peningkatan dari siklus I ke siklus II, peningkatan ini dapat dilihat pada gambar grafik dibawah ini. 


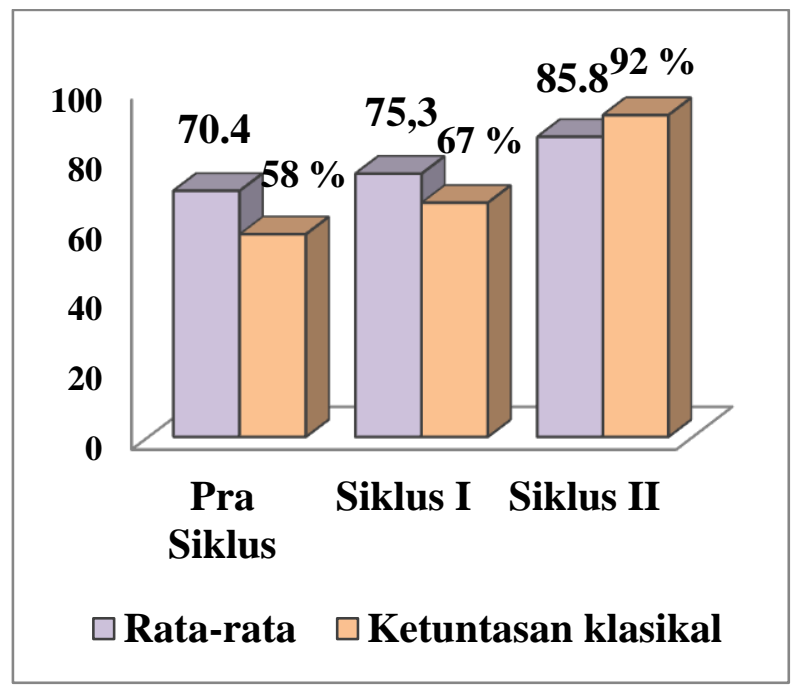

Perbandingan Peningkatan Hasil Belajar Siswa Pra Siklus, Siklus I, dan Siklus II Materi Sumber Daya Alam SDN 007 Sungai Agung

Berdasarkan gambar grafik di atas, dapat disimpulkan bahwa dengan menggunakan model pembelajaran kooperatif Two Stay Two Stray hasil belajar siswa kelas IV SDN 007 Sungai Agung materi sumber daya alam meningkat. Pada siklus II guru telah melaksanakan proses pembelajaran dengan menggunakan model pembelajaran kooperatif Two Stay Two Stray terlaksana dengan baik.

1) Siswa tidak ribut lagi dalam mengerjakan tugas 2) siswa telah bekerjasama dengan anggota

kelompoknya masing-masing dan, 3) siswa telah mengerjakan soal evaluasi dengan tenang.

2) Siswa telah berani untuk mengungkapkan pendapatnya di depan kelas

3) Siswa telah aktif dalam proses pembelajaran.

4) Siswa saling menghargai pendapat yang satu dengan yang lainnya dan siswa juga berani untuk bertanya kepada guru jika dia tidak paham dalam materi yang disampaikan guru.

\section{2).Perbandingan Peningkatan Aktivitas Belajar Siswa}

Perbandingan peningkatan aktivitas belajar siswa dari pratindakan, siklus I, dan siklus II pada materi sumber daya alam pada model Two Stay Two Stray pada tabel 4.10

Tabel 4.10 Perbandingan Hasil Peningkatan Aktivitas Belajar Siswa

\begin{tabular}{|l|l|c|c|c|}
\hline No. & \multicolumn{1}{|c|}{ Keterangan } & $\begin{array}{c}\text { Pra } \\
\text { tindakan }\end{array}$ & $\begin{array}{c}\text { Siklus } \\
\text { I }\end{array}$ & $\begin{array}{c}\text { Siklus } \\
\text { II }\end{array}$ \\
\hline 1. & Nilai rata-rata & 5,5 & 8,8 & 10,5 \\
\hline 2. & $\begin{array}{l}\text { Presentase Hasil } \\
\text { Peningkatan } \\
\text { Aktivitas Belajar }\end{array}$ & $47 \%$ & $73 \%$ & $87,5 \%$ \\
\hline
\end{tabular}

Berdasarkan tabel di atas, diketahui bahwa nilai rata-rata siswa pada pra tindakan adalah 5,5 pada siklus I meningkat menjadi 8,8 kemudian pada siklus II mengalami peningkatan menjadi 10,5 sedangkan persentase hasil peningkatan aktivitas belajar pada pratindakan adalah $47 \%$, pada siklus I meningkat menjadi 73\%, kemudian pada siklus II meningkat menjadi 87,5\%. Hal ini menunjukkan bahwa adanya peningkatan dari siklus I ke siklus II, peningkatan ini dapat dilihat pada gambar grafik 4.20 . 


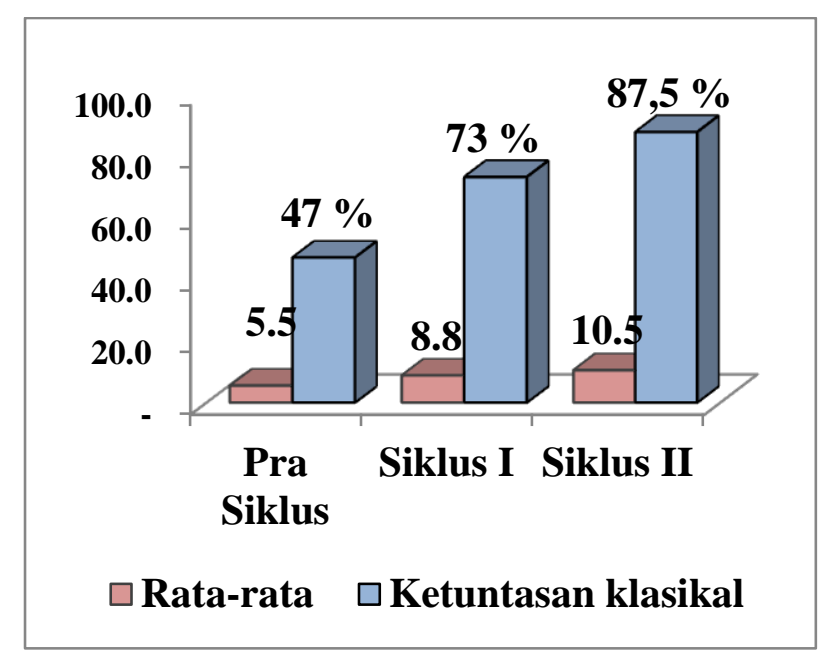

Gambar 4.20 Grafik Perbandingan Peningkatan Aktivitas Belajar Siswa Pra Siklus, Siklus I, dan Siklus II Materi Sumber Daya Alam SDN 007 Sungai Agung

Berdasarkan gambar grafik di atas, dapat disimpulkan bahwa dengan menggunakan model pembelajaran kooperatif Two Stay Two Stray Aktivitas belajar siswa kelas IV SDN 007 Sungai Agung materi sumber daya alam meningkat. Pada siklus II guru telah melaksanakan proses pembelajaran dengan menggunakan model pembelajaran kooperatif Two Stay Two Stray terlaksana dengan baik.

1). Siswa tidak ribut lagi dalam mengerjakan tugas 2) siswa telah bekerjasama dengan anggota kelompoknya masing-masing dan, 3) siswa telah mengerjakan soal evaluasi dengan tenang.

2). Siswa telah berani untuk mengungkapkan pendapatnya di depan kelas

3). Siswa telah aktif dalam proses pembelajaran.

4). Siswa saling menghargai pendapat yang satu dengan yang lainnya dan siswa juga berani untuk bertanya kepada guru jika dia tidak paham dalam materi yang disampaikan guru.

\section{Pembahasan}

\section{Perencanaan Pembelajaran Sumber Daya Alam dengan Menggunakan Model Two Stay Two Stray}

Pada perencanaan pelaksanaan siklus I dan siklus II dalam pembelajaran IPA dengan materi sumber daya alam pada siswa kelas IV SDN 007 Sungai Agung. Sebelum melaksanakan tindakan peneliti dituntut membuat perencanaan yang disusun oleh peneliti dalam penelitian ini yaitu:

Menyusun instrument penelitian berupa silabus, menyusun RPP berdasarkan langkah-langkah model Two Stay Two Stray, menyiapkan lembar observer, dan menyiapkan soal evaluasi, kemudian menjelaskan kegiatan yang harus dilakukan observer sesuai dengan lembar observasi.

Adapun komponem-konponem penting yang ada dalam rencana pelaksanaan meliputi: identitas, standar kompetensi (SK), kompetensi dasar (KD), indikator, tujuan pembelajaranh, materi pokok, model Two Stay Two Stray, langkah-langkah pembelajaran sumber pembelajaran dan penilaian.

\section{Proses Pembelajaran Sumber Daya Alam dengan Menggunakan Model Two Stay Two Stray}

Berdasarkan deskripsi pada siklus I pertemuan pertama siswa dalam menyampaikan tujuan pembelajaran sudah terlaksana dengan baik, siswa harus dibimbing lagi dalam mempersentasekan hasil kerjanya lagi dengan baik dan dalam pengerjaan evaluasi harus ada pengawasan oleh guru agar 
tidak ribut, penyebabnya karena siswa kurang memperhatikan guru saat guru memberikan gambaran secara umum tentang cara-cara pelaksanaan yang akan dilakukan siswa.

Siklus I pertemuan kedua, siswa juga masih belum terlibat aktif dalam kerja kelompok. Siswa sudah mulai bekerja sama dalam kelompok dengan baik selanjutnya perlu dibimbing lagi agar semua siswa dapat terlibat aktif dalam kerja kelompok.

Pada siklus II pertemuan pertama, masih ada siswa yang kurang menyimak dalam penguatan yang disampaikan oleh guru dan perlu ditingkatkan lagi. Siswa sudah mulai bekerjasama dalam kelompok selanjutnya perlu dibimbing lagi agar semua siswa bekerjasama dalam kelompok, penyebabnya karena ketika guru memberikan gambaran secara umum tentang hal-hal yang akan dikerjakan siswa, seluruh siswa sudah mendengarkan dengan baik.

Tindakan yang dilakukan pada pembelajaran dengan model Two Stay Two Stray telah dilakukan oleh peneliti berdasarkan langkah-langkah pembelajaran yang telah ditetapkan sebelumnya.

\section{Hasil Belajar Siswa pada Materi Sumber Daya Alam Setelah Penerapan Model Two Stay Two Stray}

Dari hasil kegiatan selama penelitian ternyata penerapan model Two Stay Two Stray sangat tepat diterapkan di kelas IV SDN 007 Sungai Agung Tahun Pelajaran 2017/2018, dalam kegiatan pembelajaran membantu individu untuk menemukan makna keberanian dalam mengerjakan tugasnya dan berupaya memecahkan masalah dengan bantuan kelompok.

Model pembelajara Two Stay Two Stray "adalah pembelajaran bertujuan untuk membantu siswa sebagai pengetahuan dan pengalaman dengan kelompok lain". Hal ini terbukti dengan adanya peningkatan hasil belajar siswa dari sebelum tindakan ke siklus I dan siklus II.

Hasil belajar siswa sebelum tindakan hanya nmendapat nilai rata-rata 70,4 yaitu jumlah siswa yang tuntas sebanyak 14 orang $(58,3 \%)$ dari 24 orang. hal ini dikarenakan guru dalam menyampaikan materi sumber daya alam cenderung menggunakan metode ceramah, sehingga siswa sulit untuk menerima Informasi untuk menerima informasi yang disampaikan guru.

Kemudian peneliti menerapkan model Two Stay Two Stray untuk meningkatkan aktivitas dan hasil belajar materi sumber daya alam, pada siswa kelas IV SDN 007 Sungai Agung, pada siklus I terjadi peningkatan nilai rata-rata pratindakan 70,4 menjadi 75,3 pada siklus I selanjutnya dari 24 orang siswa terdapat 16 orang siswa atau $67 \%$ yang mencapai ketuntasan individual, meningkat jumlah siswa yang mencapai ketuntasan individual pada siklus, dikarenakan penerapan model Two Stay Two Stray. pada siklus I terdapat8 orang $(33, \%)$ yang tidak mencapai ketuntasan, hal ini dikarenakan pada siklus I guru belum menguasai rencana pembelajaran dengan baik, sehingga banyak siswa yang belum tuntas.

Hasil belajar pada siklus II mengalami peningkatan nilai rata-rata dari siklus I 75,3, menjadi 85,8 pada siklus II, selanjutnya dari 24 orang siswa terdapat 22 orang siswa (92\%) yang mencapai ketuntasan secara individu. Peningkatan persentase ketuntasan klasikal pada siklus I ini dikarenakan guru telah melakukan perbaikan dari kekurangan-kekurangan yang terjadi pada siklus I. Hal ini dikarenakan hasil belajar siswa dapat dipengaruhi oleh berbagai macam faktor yang dibedakan menjadi dua golongan yaitu: 1) faktor internal atau faktor-faktor yang ada dalam diri siswa, 2) faktor eksternal atau faktor yang berada di luar diri siswa menurut Purwanto (2002: 102) dalam (Thobroni 2011: 31). 
Berdasarkan hasil pembahasan di atas dapat disimpulkan bahwa penerapan model Two Stay Two Stray dapat meningkatkan aktivitas dan hasil belajar siswa pada materi sumber daya alam kelas IV SDN 007 Sungai Agung Tahun Ajaran 2017/2018.

\section{KESIMPULAN, IMPLIKASI DAN SARAN \\ Kesimpulan}

Berdasarkan hasil penelitian dan pembahasan, maka dapat disimpulkan sebagai berikut:

1. Penggunaan model Two Stay Two Stray dapat meningkatkan Aktivitas dan hasil belajar IPA siswa kelas IV SDN 007 Sungai Agung. Secara produk hasil belajar IPA terlihat dari meningkatnya hasil belajar siswa dan mencapai kriteria keberhasilan yaitu $80 \%$ siswa yang diukur dengan soal evaluasi pada akhir pertemuan. Berdasarkan hasil tes yang diperoleh siswa pada setiap akhir siklus menunjukkan peningkatan hasil belajar IPA.

2. Berdasarkan hasil penelitian yang sudah dipaparkan di atas maka dapat disimpulkan beberapa hal terkait penelitian sebagai berikut:

\section{1).Perencanaan Pembelajaran IPA materi Sumber Daya Alam dengan Penggunaan Model Two Stay Two Stray}

Perencanaan pembelajaran IPA materi Sumber Daya Alam dengan menggunakan model pembelajaran kooperatif Two Stay Two Stray sebelum melaksanakan tindakan terdapat beberapa hal yang harus disiapkan, yaitu:

1. Menyusun Silabus

2. Menyusun RPP berdasarkan model pembelajaran kooperatif Two Stay Two Stray

3. Menyiapkan lembar observasi aktivitas guru dan siswa

4. Meminta kesediaan guru kelas menjadi observer

5. Menyiapkan alat evaluasi atau tes.

\section{2).Proses Pembelajaran IPA dengan Menggunakan Model Two Stay Two Stray pada Materi Sumber Daya Alam}

Proses pembelajaran IPA pada materi sumber daya alam yang dilaksanakan guru pada siklus I secara keseluruhan telah dilaksanakan sesuai dengan RPP, namun belum terlaksana dengan baik, sedangkan pada siklus II secara keseluruhan proses pembelajaran terlaksanadengan baik, karena guru telah melaksanakannya sesuai dengan RPP, selain itu tahap demi tahap Two Stay Two Stray telah terlaksana dengan baik. Meningkatnya aktivitas guru pada siklus II disebabkan guru telah menindak lanjuti kekurangan-kekurangan yang terjadi pada siklus sebelumnya dan memperbaiki pada siklus II. Sedangkan aktivitas siswa siklus I belum berjalan secara kondusif, kemampuan siswa dalam bekerja kelompok memerlukan bimbingan guru, model Two Stay Two Stray memerlukan bimbingan serta penggunaan waktu agar dapat memaksimalkan. Siklus II kemampuan siswa dalam bekerja kelompok tidak perlu bimbingan guru, serta penggunaan waktu yang lebih efektif.

\section{3).Hasil Pembelajaran IPA dengan Menggunakan Model Two Stay Two Stray pada Materi Sumber Daya Alam}

Hasil belajar siswa pada materi sumber daya alam setelah menggunakan model pembelajaran Two Stay Two Stray di kelas IV SDN 007Sungai Agung mengalami peningkatan yaitu pada siklus I hasil nilai rata-rata 75,3 dengan ketuntasan klasikal 16 orang siswa atau 67\% kemudian pada siklus II rata- 
rata hasil belajar meningkat menjadi 85,8 dengan ketuntasan klasikal meningkat menjadi 22 orang siswa atau $92 \%$. Sedangkan hasil peningkatan aktivitas belajar siswa pada siklus I nilai rata-rata 8,8 atau $73 \%$ kemudian pada siklus II nilai rata-rata aktivitas belajar meningkat menjadi 10,5 atau $87,5 \%$.

\section{Saran}

1. Guru diharapkan dapat menentukan model pembelajaran yan tepat dan cocok dengan materi pembelajaran agar siswa tidak bosan salah satunya disarankan menggunakan model pembelajaran Kooperatif Two Stay Two Stray karena model ini telah terbukti dapat meningkatkan aktivitas dan hasil belajar siswa.

2. Untuk menigkatkan kualitas sekolah, disarankan kepada kepala sekolah untuk lebih mengawasi proses pembelajaran di kelas, agar kegiatan belajar mengajar yang dilaksanakan guru dapat dilaksanakan dengan baik.

3. Untuk peneliti selanjutnya, terutama yang akan meneliti dengan menggunakan model pembelajaran Kooperatif Two Stay Two Stray disarankan untuk lebih menguasai kelas dalam pembagian kelompok dan mampu memaksimalkan penggunaan waktu dalam model pembelajaran kooperatif Two Stay Two Stray terhadap mata pelajaran dan materi pembelajaran yang akan diteliti. 


\section{DAFTAR PUSTAKA}

Arikunto, Suharsimi. (2007). Penelitian Tindakan Kelas. Bumi Aksara. Jakarta

Daitin, T. (2014). Meningkatkan Aktivitas Belajar Siswa dengan Menggunakan Model Make A Match pada Mata Pelajaran Matematika di Kelas V SDN 050687 Sawit Seberang. Jurnal Kreno, 5 (1), 56-62

Darmono, A. (2016). Pendekatan Edutaiment dalam Pembelajaran IPA SD. Artikel Penelitian.

Depdiknas, (2007). Kurikulum Tingkat Satuan Pendidikan. Jakarta: Alfabeta

Dewi, A. N., Rati, N. W., \& Dibia, I. K. (2016). Penerapan Model Pembelajaran Kooperatif Tipe Snowball Throwing untuk Meningkatkan Aktivitas. e-Journal PGSD Universitas Pendidikan Ganesha, 4 (1), 1-10.

Sanjaya, W. (2010). Penelitian Tindakan Kelas. Jakarta: Kencana Prenada Media Group.

Sukarsa, I. W., Dantes, N., \& Arini, N. W. (2014). Penerapan Model Pembelajaran Kuantum Berbantuan Media Microsoft Powerpoint untuk Meningkatkan Aktivitas dan Hasil Belajar IPA Siswa Kelas IV Semester 1 SD Negeri 6 Menaga. Jurnal Mimbar PGSD Universitas Pendidikan Ganesha, 2 (1).

Sugiyono. (2010). Metode Penelitian Pendidikan. Alfabeta. Bandung.

Surya, Y (2017). Penerapan Model Numbered Head Toghether untuk Meningkatkan Hasil Belajar Ips Kelas IV SD.

Tampubolon, S. (2014). Penelitian Tindakan Kelas. Penerbit Erlangga. Jakarta

Thobroni, M., \& Mustofa, A. (2011). Belajar \& Pembelajaran. Jogjakarta: Ar- Ruzz Media Thobroni, Mustofa. (2011). Belajar dan Pembelajaran. Yogyakarta: Ar-ruzz Media.

Trianto. (2011). Mendesain Model Pembelajaran Inovatif-Progresif. Jakarta: Kencana Prenada Media Group.

(2017). Model Pembelajaran Terpadu. Jakarta: Bumi Aksa 